\title{
THE EFFECTIVENESS OF REALISTIC MATHEMATICS EDUCATION (RME) APPROACH IN MATHEMATICS LEARNING OF STUDENTS IN MTs NEGERI GODEAN SLEMAN
}

\author{
Fitria $^{\text {a }}$, Edi Prajitno ${ }^{\mathrm{b}}$ \\ Program Studi Pendidikan Matematika Universitas Ahmad Dahlan \\ Jalan Ring Road Selatan, Tamanan, Banguntapan, Bantul Yogyakarta \\ afitriafitri03@gmail.com, ${ }^{\text {bediprajitno@yahoo.com }}$
}

\begin{abstract}
Teacher-centered learning often makes students feel bored and not interested in participating in learning mathematics. This causes students to be less active in learning activities so that students become less familiar with the material described by teachers and resulted in low learning outcomes of mathematical learning. This study aims to determine whereas more effective learning between mathematics learning using the Realistic Mathematics Education (RME) approach with mathematics learning using a traditional approach to mathematics learning outcomes of students. The population in this study is the seventh-grade students of MTs Negeri Godean Sleman in the academic year 2015/2016 which consists of 4 classes. The sampling technique using a purposive sampling technique (sampling technique with certain considerations) to the class that obtained class VII B as an experimental class and class VII A as a control class. The data was collected using the test method. Instrument testing used validity, reliability, and difficulty level. The data analysis technique used analysis prerequisites of normality test, homogeneity test, and hypothesis testing. The result showed that 1) there is a different learning outcome between learning mathematics using the Realistic Mathematics Education (RME) approach with learning mathematics using a traditional approach. It's based on two-tailed t-test obtained $t_{\text {cal }}^{\prime}=2,3092$ and $t_{\text {table }}=2,038$ with a significance level of $5 \%$ and the degrees of freedom, respectively $n_{1}-1=31$ and $n_{2}-1=31$, which meanings $t_{c a l}^{\prime}>t_{\text {table }}$, and than $H_{0}$ is rejected and $H_{1}$ accepted. 2) Learning mathematics using the Realistic Mathematics Education (RME) approach is more effective than learning mathematics using the traditional approach through mathematics learning outcomes on seventh-grade students of MTs Negeri Godean Sleman in the academic year of 2015/2016. It is based on the one tiled t-test obtained $t^{\prime}$ cal $=2,3092$ and $t_{\text {table }}=1,698$ with a significance level of $5 \%$ and the degrees of freedom, respectively $n_{1}-1=31$ and $n_{2}-1=31$, which meanings $t_{c a l}^{\prime}>$ $t_{\text {table }}$, and than $H_{0}$ is rejected and $H_{1}$ accepted.
\end{abstract}

Keywords: effectiveness, Realistic Mathematics Education, learning outcomes.

\section{INTRODUCTION}

Education is the most important and very influential thing in one's life. The purpose of education is to create a quality and character personality so that they have a broad vision in the future to reach the expected goals and be able to adapt in a variety of environments. Definition of Education according to the National Education System Law No. 20 of 2003 is a conscious and planned effort to create a learning atmosphere and learning process so that students actively develop their potential to have religiousspiritual strength, self-control, personality, intelligence, noble character and skills needed by themselves, society, nation and country and National Education is expected to be achieved. The existence of mathematics is not uncommon to make some students feel difficulty in learning it. Mathematics whose objects are abstract makes it difficult for some students to understand and apply them in real life. Difficulties of students learning mathematics not only because the object is abstract but other factors can also make it difficult for students to learn mathematics. Such as the delivery of material by educators using methods that are not appropriate. And in learning mathematics that is separate from everyday experience will make students quickly forget and difficult to apply mathematics in real life.

Based on the results of interviews with one of the mathematics teachers at Godean State MTs, Yogyakarta on October 12 and November 23, 2015, that in mathematics learning still used the conventional method of learning, namely learning with the lecture method accompanied by explanation and division of tasks and training. And from the results of interviews, some students say that mathematics 
is one of the subjects that are difficult compared to other subjects. They find it difficult to understand the material because so many formulas or symbols must be understood, thus making students less interested in the learning process of mathematics in the classroom.

Based on the observations of researchers in class, the learning process with this conventional approach is still dominated by the teacher so that this learning seems monotonous and there is saturation in students. Students are also difficult to understand the material that has been explained and are less active in the learning process in class. Besides that students are also less creative in solving a mathematical problem. It is clear from the results of the average midterm test scores, that students who can achieve or meet the minimum completeness criteria (KKM) standards that have been determined by the school are only 75 or a percentage of $<50 \%$.

Learning is the process of changing new behaviors of individuals who have directed goals and are beneficial to the environment and the individual itself. And learning is a process of interaction of a teacher with students and learning resources to achieve more optimal goals. In this case, learning and learning are inseparable. This means that a learning process can run well because of the learning process, where the learning process is more emphasized in students and learning is more emphasized on the teacher as a facilitator.

Treffers in Wijaya, Ariyadi (2012: 21) formulated five characteristics of Realistic Mathematics Education, namely:

1) Use of context

Realistic contexts or problems are used as the starting point for learning mathematics. Context does not have to be a real-world problem but it can be in the form of games, props, or other situations as long as they are meaningful and can be imagined in the minds of students.

2) Use of models for progressive mathematics

In Realistic Mathematics Education, models are used to progressively mathematicize. The use of a model functions as a bridge (bridge) from a concrete level of knowledge and mathematics to formal mathematical knowledge.

3) Utilization of student construction results

Referring to Freudenthal's opinion that mathematics is not given to students as a product that is ready to be used but as a concept built by students, then in Realistic Mathematics Education students are placed as subjects of learning. Students have the freedom to develop problem-solving strategies so that various strategies are expected to be obtained. The work and construction of students are then used as a basis for developing mathematical concepts.

4) Interactivity

A person's learning process is not the only individual but also simultaneously is a social process. Student learning will be shorter and meaningful when students communicate with each other the results of their work and ideas. The use of interactions in mathematics learning is useful in developing students' cognitive and affective abilities simultaneously.

5) Linkages

Realistic Mathematics Education places intertwinement between mathematical concepts as things that must be considered in the learning process. One mathematics learning is expected to be able to introduce and build more than one mathematical concept simultaneously.

According to Suprijono in Thobroni, Muhammad (2011: 22), said that learning outcomes are patterns of actions, values, understandings, attitudes, appreciation, and skills. According to Keller in Abdurrahman, Mulyono (2012: 27), learning outcomes are actual achievements displayed by children." Meanwhile, according to Abdurrahman, Mulyono (2012: 27), learning outcomes are also influenced by children's intelligence and initial mastery of the material to be learned. According to Mulyasa, E (2005: 82), argues that: Understanding effectiveness is related to the implementation of the main tasks, the achievement of goals, the timeliness and the active participation of members. The effectiveness problem is usually closely related to the comparison between the level of achievement of goals and plans that have been prepared beforehand. 
Sadiman in Trianto (2009: 20) said that the effectiveness of learning is the result of use obtained after the implementation of the teaching and learning process. One approach in mathematics education that has been developed in the Netherlands Netherlands is a realistic mathematical learning approach. This approach refers to the opinion of Freudenthal in Wijaya, Ariyadi (2012: 20) which states that "Mathematics is a human activity. This means that mathematics must be relevant to students' daily lives and can provide the widest opportunity for students to rediscover mathematical ideas and concepts. This approach is then known as Realistic Mathematics Education (RME)

In realistic mathematics education, teachers must develop interactive teaching and provide opportunities for students to actively participate in their learning process. Majid, Abdul (2013: 165) argues that: Conventional learning is defined as learning in a classical context that is used to being done which is teacher-centered so that implementation does not pay attention to the whole learning situation (noncomplete learning).

The objectives to be achieved in this study are as follows.

1. To find out whether or not there are differences in learning outcomes of students who get learning using a realistic mathematics learning approach with students who get conventional learning in class VII MTs Negeri Godean Sleman 2015/2016 Academic Year.

2. To find out more effective learning between mathematics learning using the RME approach with mathematics learning that uses a conventional approach to class VII students of MTs Negeri Godean Sleman 2015/2016 Academic Year.

\section{METHODS}

This research is a type of experimental research. The population in this study were VII grade students in the even semester of MTs Negeri Godean Sleman Regency 2015/2016 academic year which consisted of 4 classes namely VII A, VII B, VII C, and VII D. In this study, sample selection used Purposive Sampling. According to Sugiyono (2015: 124), purposive Sampling is a technique of determining samples with certain considerations. This technique is done by direct appointment of a population consisting of 4 classes so that class VII B is obtained as an experimental class that will be given learning with a Realistic approach Mathematics Education and VII-A class as a control class. While the trial class was conducted in class VII D. The data collection techniques used were documentation techniques and test techniques. Documentation techniques are used to determine the students initial mathematical abilities before the experiment is conducted, while the test technique is used to evaluate students' mathematics learning outcomes. The research instrument test used is a validity test, different power tests, and a reliability test. Then for the analysis prerequisite test used is the normality test and homogeneity test. Data analysis for hypothesis testing using a two-part hypothesis test and one part hypothesis test.

\section{RESULTS AND DISCUSSION}

\section{Early Ability}

\section{a. Description of Initial Capabilities}

The initial ability value is obtained from the value of the Even Semester UTS. The results of the experimental class are the highest 83 , the lowest value is 38 , the average is 60.5313 , the standard deviation is 9.333 and the variance is 87.1603 . While the results of the control class are the highest 80 , the lowest value is 58 , the average is 68.7188 , the standard deviation is 6.7117 and the variance is 45.0474 .

\section{b. Preliminary Ability Value Normality Test Results}

Based on the results of the normality test the value of the initial ability in the experimental class $\chi_{\text {cal }}^{2}=0,60667$ and $\chi_{\text {table }}^{2}=7,815$ with a significant level of 5\% and a degree of freedom 31 , which means $\chi_{\text {cal }}^{2}<\chi_{\text {table }}^{2}=$ so it can be concluded that the initial ability of the experimental class is normally distributed data. Whereas in the control class $\chi_{\text {cal }}^{2}=2,33842$ and $\chi_{\text {table }}^{2}=$ 
7,815 with a significant level of $5 \%$ and the degree of freedom 31 , which means $\chi_{\text {cal }}^{2}<\chi_{\text {table }}^{2}$ so that it can be concluded that the initial ability of the control class is normally distributed data.

c. Initial Capability Homogeneity Test Results

Based on the test results the homogeneity of the value of the initial capability is obtained $\chi_{\text {cal }}^{2}=$ 3,312 and $X_{\text {tabel }}^{2}=3,8415$ at a significant level of 5\% and the degree of freedom 1 . Which means $\chi_{\text {cal }}^{2}<\chi_{\text {table }}^{2} \mathrm{~s}$ so that it can be concluded that the sample has a homogeneous variance.

d. Average Initial Test Value of Similarity Test Results

Based on the test results the similarity of the average value of the initial ability is obtained $t_{c a l}=$ $-4,0281$ and $t_{\text {table }}=1,9993$, so $t_{\text {cal }}<t_{\text {table }}$, which means $\mathrm{H}_{0}$ is accepted. So, it can be concluded that there is no difference in the value of students' initial abilities between class VII B (Experiment) and class VII A (Control) of MTs Negeri Godean Sleman 2015/2016 Academic Year.

\section{Mathematics Learning Results}

a. Description of the Value of Mathematics Learning Outcomes Test

The results of the mathematics learning outcomes test results from the experimental class are with the highest value of 87.50 , the lowest value of 50.00, the average of 72.2656, the standard deviation of 7.7670 and the variance of 60.3264 . Whereas the results of the control class are highest with 93.75, the lowest value 43.75, average 65.8203, standard deviation 13.7467 and variance 188.9727. The results of the mathematics learning outcomes test results from the experimental class are with the highest value of 87.50, the lowest value of 50.00, the average of 72.2656 , the standard deviation of 7.7670 and the variance of 60.3264 . Whereas the results of the control class are highest with 93.75 , the lowest value 43.75 , average 65.8203 , standard deviation 13.7467 and variance 188.9727.

b. Normality Test Results Value Test Mathematics Learning Outcomes

Based on the results of the normality test of the learning outcomes test results in the experimental class $\chi_{\text {cal }}^{2}=1,68868$ and $\chi_{\text {table }}^{2}=5,9915$ with a significant level of 5\% and a degree of freedom 31 , which means $\chi_{\text {cal }}^{2}<\chi_{\text {table }}^{2}$ so that it can be concluded that the test results of the experimental class learning outcomes are normally distributed data. Whereas in the control class $\chi_{\text {stat }}^{2}=1,745007$ and $\chi_{\text {table }}^{2}=5,9915$ with a significant level of $5 \%$ and a degree of freedom 31 , which means $\chi_{\text {cal }}^{2}<\chi_{\text {table }}^{2}$ so that it can be concluded that the value of the test results of the control class is normally distributed data.

c. Homogeneity Test Results Learning Outcomes Test Value

Based on the test results the homogeneity of the value of the learning outcomes test is obtained $\chi_{\text {cal }}^{2}=9,6007$ and $\chi_{\text {table }}^{2}=3,8415$ at a significant level of $5 \%$ and the degree of freedom 1 . Which means $\chi_{\text {cal }}^{2}>\chi_{\text {table }}^{2}$ so that it can be concluded that the sample has a non-homogeneous variance.

\section{d. Hypothesis testing}

1. Test Results of the Two Parts Hypothesis

Based on the results of the two-part hypothesis test obtained that the value $t^{\prime}{ }_{\text {cal }}=2,3092$ and $\frac{w_{1} t_{1}+w_{2} t_{2}}{w_{1}+w_{2}}=2,038$ at a significant level of $5 \%$ and degrees of freedom each of $n_{1}-1=31$ and $n_{2}-1=31$ which means $t_{c a l}^{\prime}>\frac{w_{1} t_{1}+w_{2} t_{2}}{w_{1}+w_{2}}$, so $\mathrm{H}_{0}$ is rejected and $\mathrm{H}_{1}$ is accepted. Thus, there are differences in mathematics learning outcomes between students who use learning with a realistic mathematics education approach and students' mathematics learning outcomes with conventional learning.

2. One-part Hypothesis Test Results

Based on the results of the hypothesis test one part obtained that value $t^{\prime}{ }_{c a l}=2,3092$ and $\frac{w_{1} t_{1}+w_{2} t_{2}}{w_{1}+w_{2}}=1,698$ at a significant level of $5 \%$ and the degree of freedom of each $n_{1}-1=$ 
31 and $n_{2}-1=31$ which mean $t_{c a l}^{\prime} \geq \frac{w_{1} t_{1}+w_{2} t_{2}}{w_{1}+w_{2}}$, so that $\mathrm{H}_{0}$ is rejected and $\mathrm{H}_{1}$ is accepted. Thus, learning mathematics by using a realistic mathematics education approach is more effective than conventional learning on the mathematics learning outcomes of seventh graders in the even semester of MTs Negeri Godean Sleman in the 2015/2016 Academic Year.

\section{CONCLUSION}

Based on the results of research and discussion, it can be concluded that:

1. There are differences in learning outcomes between students who get learning using the Realistic Mathematics Education approach with students who get conventional learning in class VII students in the even semester of MTs Negeri Godean in the 2015/2016 academic year. This is shown from the results of the two-part t-test data on the test scores of student learning outcomes obtained values $t_{\text {cal }}^{\prime}=2,3092$ and $t_{\text {table }}=2,038$ at a significant level of $5 \%$ and the degree of freedom of each $n_{1}-1=31$ and $n_{2}-1=31$ which mean $t_{\text {cal }}^{\prime}>t_{\text {table }}$, so $\mathrm{H}_{0}$ is rejected and $\mathrm{H}_{1}$ is accepted.

2. 2. Learning mathematics using the Realistic Mathematics Education approach is more effective than conventional learning on the mathematics learning outcomes of class VII students in the even semester of MTs Negeri Godean in the 2015/2016 academic year. This is indicated by the results of the t-test of the one-part test data on student learning outcomes obtained by the value $t^{\prime}{ }_{c a l}=2,3092$ and $t_{\text {table }}=1,698$ at a significant level of $5 \%$ and the degree of freedom of each $n_{1}-1=31$ and $n_{2}-1=31$ which mean $t_{c a l}^{\prime} \geq t_{\text {table }}$, so $\mathrm{H}_{0}$ is rejected and $\mathrm{H}_{1}$ is accepted.

\section{REFERENCES}

Abdurrahman, Mulyono. 2012. Anak Berkesulitan Belajar. Jakarta: PT Rineka Cipta.

Majid, Abdul. 2013. Strategi Pembelajaran. Bandung: PT Remaja Rosdakarya.

Mulyasa, E. 2005. Manajemen Berbasis Sekolah. Bandung: PT Remaja Rosdakarya.

Thobroni, Muhammad dan Arif Mustofa. 2011. Belajar dan Pembelajaran. Jogjakarta: Ar-Ruzz Media.

Trianto. 2009. Mendesain Model Pembelajaran Inovatif-Progresif. Jakarta: Kencana Prenada Media Group.

Wijaya, Ariyadi. 2012. Pendidikan Matematika Realistik. Yogyakarta: Graha Ilmu. 